\title{
Common usage of cardiologic anatomical terminology: critical analysis and a trilingual discussion proposal
}

\author{
Uso comum da terminologia anatômica cardiológica: análise crítica e proposta de discussão trilingue
}

\author{
Alexandre Lins WERNECK ${ }^{1}$, Fernando BATIGÁLIA²
}

RBCCV 44205-1091

\begin{abstract}
Background: Terminology and Lexicography have been especially addressed to the Allied Health Sciences regarding discussion of case reports or concerning publication of scientific articles. The knowledge of Human Anatomy enables the understanding of medical terms and the refinement of Medical Terminology makes possible a better anatomicomedical communication in a highly technical level. Most of the scientific publications in both Anatomy and Medicine are found only in English and most of dictionaries or search resources available do not have specificity enough to explain anatomicomedical, terminological, or lexicographical occurrences.

Objective: To design and produce a multilingual terminological dictionary (Latim-English-PortugueseSpanish) containing a list of English anatomicomedical terms in common usage in cardiology subspecialties addressed to medical students and professionals, to other allied health sciences professionals, and to translators working in this specific field.

Methods: Terms, semantical and grammatical components were selected to compose an anatomicocardiological corpus. The adequacy to the thematic terminological research requests and the translation reliability level will be settled from the terminology specificity in contrast to the semantics,
\end{abstract}

1. Translator; Post-graduate Student; Health Sciences Stricto Sensu Post-Graduate Programme; São José do Rio Preto Medical School (FAMERP); São José do Rio Preto, São Paulo, Brazil.

2. M.D.; Human Anatomy Tutor; Health Sciences Stricto Sensu Post-Graduate Programme; São José do Rio Preto Medical School (FAMERP); São José do Rio Preto, São Paulo, Brazil.

This study was carried out at Health Sciences Stricto Sensu PostGraduate Programme; São José do Rio Preto Medical School (FAMERP); São José do Rio Preto, São Paulo, Brazil. as well as from a peer survey of the main terms used by national and international experts in specialized journals, Internet sites, and from text-books on Anatomy and Cardiology. The inclusion criteria will be the terms included in the English, Portuguese, and Spanish Terminologia Anatomica - the official terminology of the anatomical sciences; nonofficial technical commonly used terms which lead to terminology or translation misunderstanding often being a source of confusion.

Results: A table with a sample of the 508 most used anatomical cardiologic terms in English language peerreviewed journals of cardiology and (pediatric and adult) thoracic surgery is shown.

Conclusions: The working up of a multilingual terminological dictionary reduces the risk of ambiguities, inconsistencies, inutilities, and repetitions concerning the Nomenclature addressed to the Allied Health Sciences by prioritizing the inclusion of official technical terms and a judicious selection of commonly used terms. Efforts to standardize lists of structures in Humana Anatomy lead to both opportunities of scientific update and conceptual enlightenment.

Descriptors: Dictionary. Terminology. Anatomy. Cardiology. Translations.

Correspondence address:

Alexandre Lins Werneck

Rua Rio Mamoré, 287 - Jardim Aclimação - 15091-410 - São José do Rio Preto, SP, Brazil.

E-mail: alexandrewerneck@uol.com.br 


\section{Resumo}

Introdução: A Terminologia e a Lexicografia têm sido principalmente aplicadas em Ciências da Saúde na discussão de relatos de casos ou na publicação de artigos científicos. $O$ conhecimento da Anatomia Humana permite compreender termos médicos, e o refinamento da Terminologia Médica possibilita melhor comunicação anatomomédica em nível altamente técnico. Grande parte das publicações científicas em Anatomia e Medicina encontra-se somente em língua inglesa, e a maioria dos dicionários ou dos recursos de busca disponíveis não apresenta especificidade para explicitar ocorrências anatomomédicas, terminológicas ou lexicográficas.

Objetivo: Elaborar um dicionário terminológico em Cardiologia, trilíngue (inglês-português-espanhol), expresso por lista de termos e fraseologias anatomomédicas de níveis médio e avançado usualmente empregados em subespecialidades cardiológicas, dirigido a estudantes ou profissionais das áreas de Saúde e da Tradução.

Métodos: Foram selecionados termos e informações gramaticais e semânticas para a compilação de um corpus anatomocardiológico, pela inclusão de vocábulos presentes nas Terminologias Anatômicas Oficiais em línguas inglesa, portuguesa e espanhola, bem como termos não-técnicos utilizados para expressar posições, movimentos, condições,

\section{INTRODUCTION}

It is important for medical students to have a sound knowledge and understanding of the basic anatomical terms [1] taking into account that Anatomy forms the basis for the practice of medicine. Anatomical terminology leads the physician towards an understanding of a patient's disease, whether he or she is carrying out a physical examination or using the most advanced imaging techniques [2]. It is important not only the understanding of medical anatomical terms, but to place the terms within their proper context, that is, to give an appreciation of how the human body functions in both health and disease [3].

The accurate use of anatomical terms by medical and allied health sciences personnel enables them to communicate with their colleagues both nationally and internationally. Without anatomical terms, one cannot discuss or record accurately the abnormal functions of joints, the actions of muscles, the alteration of position of organs, or the exact location of swellings or tumors [1]. Anatomical terms are also important for dentists, chiropractors, physical therapists, and others involve in any aspect of patient treatment that begins with an analysis of clinical signs. The ability to interpret a clinical observation correctly is therefore, the endpoint of a sound anatomical terminology understanding. Thus, an understanding of anatomical terms requires an understanding of the context in which the terminology can be remembered [2].

Terminology and Lexicography, in Health Sciences, are procedimentos ou lesões que ocasionem erros de terminologia ou de tradução anatomomédicas. A adequação às necessidades da pesquisa terminológica temática e o grau de confiabilidade tradutológica foram determinados a partir da especificidade da terminologia frente à semântica e de levantamento criterioso dos principais termos utilizados por especialistas nacionais e internacionais em periódicos, sites e compêndios em Anatomia e Cardiologia.

Resultados: Apresentamos uma tabela com uma amostra de 508 termos anatomocardiológicos mais usados em língua Inglesa, consagrados em periódicos de cardiologia e cirurgia torácica (adulto e infantil).

Conclusões: A elaboração de um Dicionário Terminológico multilíngue em Anatomia Cardiológica reduz o risco de ambiguidades, incoerências, inutilidades e repetições em Nomenclatura, direcionada às Ciências da saúde, ao priorizar a inclusão de termos oficiais e uma seleção criteriosa de vocábulos comumente utilizados. Esforços em padronizar listas de estruturas em Anatomia Humana promovem oportunidades de atualização científica e de esclarecimento conceitual.

Descritores: Dicionário. Terminologia. Anatomia. Cardiologia. Tradução.

generally used when physicians discuss case reports and when medical papers are published. Terminology establishes with Translation extremely close relationships, once performing their professional activities, translators of technical-scientific texts need to consult the lexical material resulting from the terminological practice, either being mono, bi-, or, even multilingual. These lexical materials are the glossaries, terminological dictionaries, and terminological database, among others relevant materials [4].

It seems rather unnecessary to say that Anatomy has an international vocabulary that is the foundation of medical terminology, thus, it is highly important that all health professionals throughout the world use the same terms $[5,6]$. The technical-scientific vocabulary is, along with other lexicographic compositions, one of the vital instruments to clipping scientific "events” in order to store and retrieval of these data to accomplish a more intensive and efficient communication among specialists within and among scientific areas. Moreover, it is highlighted as an important instrument of research and support of the theoretical framework of the science itself [7].

Unfortunately, the terminology commonly used in hospitals, textbook, atlases or articles may differ from the official terminology. Because this discrepancy may be source of confusion, misunderstanding, misinterpretation [7], we decided to draw attention to the differences between both official and nonofficial terminology to enlighten the practitioners, health science students, translation students, and to a large extent dispel the confusion exiting up to the present moment. 
The aim of the present study is to promote a critical analysis and a brief discussion among official and alternative official terms, nonofficial technical terms, and common usage terms in English, Portuguese, and Spanish commonly used in cardiologic subspecialties.

\section{METHODS}

Considering the Terminology specific orientation, the selection of the terms which composes the lexical universe - the vocable (terms), the standard units of techno-scientific vocabulary, and the word-occurrence sets - was not conducted in the same way as that of developing a general language dictionary.

The type of bibliographic source varied according to the aims of the study. At first sight, one of the sources to be privileged was the text to which we had access to both the original manuscript and its translation. The consultation to the specialists of specific subject fields, calling forth their precious expertise, as well as their nation- and worldwide representativity, eliminates or mitigates the effect of the terminological dialects [4].

Another criterion, innately and purely quantitative, which could guide the task of selecting the terminological units to be analyzed, is the "reliability index" (the level of acceptability, advisability, and reliability). The main reliability codes usually employed by the terminologists are: normalized term, privileged term, admitted term, and rejected term. The codes can also include the following: term to be avoided, correct term, official term, nonofficial technical term, etc. Examples: internal mammary artery is a term to be avoided; the correct and official anatomical term is: internal thoracic artery; circumflex artery is an unofficial term; circumflex branch of the left coronary artery is the official anatomical term. Another example of the abovementioned is: arteriovenular anastomosis; although arteriovenous anastomosis is widely used, for the sake of correctness arteriovenular anastomosis is the preferred term, since the structure in question does not link an artery and a vein, but an arteriole and a venule $[6,8]$.

Based on the identified critical issues and concepts aforementioned, we came to identify relevant Medical Subject Headings (MeSH) terms, Health Sciences Descriptors (DeCS) terms, and terms in English language, peer-reviewed scientific literature, such as The Annals of Thoracic Surgery (the Official Journal of the Society of Thoracic Surgeons and the Southern Thoracic Surgical Association), the Journal of Thoracic and Cardiovascular Surgery (the Official Publication of the American Association of the Thoracic surgery and the Western Thoracic Surgical Association), and the Brazilian Journal of Cardiovascular Surgery (Official Journal of the Brazilian Society of Cardiovascular Surgery). In order to give more credibility to our research, the Terminologia Anatomica (English and Latin), the Terminologia Anatômica (Portuguese), and the Terminología Anatómica (Spanish) were also used to compile the Official Anatomical Terms and give more reliability to the present research. Only the Latin list of terms should be used as the basis for creating lists of equivalents terms in other languages. English, Portuguese, and Spanish equivalents are given in this list as they are spoken in their respective countries.

Table 1 with a sample of the 30 main used official Cardiologic Terms in Latin, English, Portuguese and Spanish, and Table 2 with 30 English, Portuguese, and Spanish main cardiologic terms in common usage peerreviewed journals of cardiology and (pediatric and adult) thoracic surgery are provided.

\section{RESULTS}

The terms are laid out in four columns, with each Latin term accompanied by a term in current usage in English-, Portuguese-, and Spanish-speaking countries. These are the Official Standard Anatomical Terms according to each Terminologia Anatomica of each country. Only Latin list of terms should be used as the basis for creating lists of equivalent terms in other languages. English equivalents are given in this list as English is spoken in many countries.

\section{DISCUSSION}

The aims of the terminological research determine the terminological set units that a Nomenclature of a speciality vocabulary should be composed of. The accuracy in identifying the addressed subdomains and a counterbalanced research are the only guarantee of establishing a homogeneous terminological set, thus presenting several advantages such as: to the reader, it allows to clearly know what kind of term, he/she will find in the book; to the terminologist, it allows to make choices concerning the nomenclature boundaries, to identify the derangements and the lack of homogeneity in the usage of the subdomains allowing the professional to correct occasional distortions in the further nomenclature of the vocabulary [8].

Anatomy - the study of the structure and function of the human body - first studied formally in Egypt, approximately $500 \mathrm{BC}$, is one of the oldest basic medical sciences. The earliest descriptions of Anatomy were written on papyruses between 3000 and 2500 BC. Hyppocrates, who is regarded as the Father of Medicine and a founder of the science of Clinical Anatomy, wrote several books on Anatomy. In one he stated: "The nature of the body is the beginning of medical science” [9]. Vesalius' masterpiece De Humani Corporis Fabrica, published in 1543, marked a new era in the history of medicine. The study of Anatomy 
suddenly became an objective a scientific discipline based on direct observations as well as scientific principles. Vesalius concluded the preface of his Fabrica with the statement that Anatomy "should rightly be regarded as the firm foundation of the whole art of Medicine and its essential preliminary" [10].

Anatomy and Medicine have an international vocabulary. Although you might be familiar with common terms for parts and regions of the body, you must learn the correct nomenclature (axilla instead of armpit and clavicle instead of collar bone, for example) that enables precise communication among health care professionals worldwide, as well as among scholars in basic and Applied Health Sciences. Nevertheless, you must also know what the common terms refer to so that you can un-derstand the words patients use when they describe their complaints. You must also use terms that they can understand when you explain their medical problems to them $[10,11]$.

A subject such as Anatomy, with its accent on description, necessarily requires a very large number of names for structures and processes. It must be said at once that the officially and internationally agreed terms (Table 1) are not always adhered to in articles, textbooks, or atlases [12]. Unfortunately, the terminology commonly used in hospitals, textbook, atlases or articles may differ from the official terminology (Table 2). Because this discrepancy may be source of confusion, we aim to clarify commonly confused terms by placing the unofficial designations in parenthesis when the terms are first used, for example: internal thoracic artery (internal mammary artery); transversus thoracis (sternocostalis); conducting system of heart (cardiac conduction system) [10,11].

Aubert [4] highlighting the above mentioned gap between the terminology commonly used in hospitals, textbooks, atlases, articles, and by practitioners and the official terminology, states that besides making the translation task harder and arduous it would infallibly lead to a proliferation of terms because the translator is tempted to take personal decisions, which not always are concordant with that of other translators, or other practitioners pertaining to the analyzed health fields.

A good example of this would be the following terms: anterior interventricular branch, an official anatomical term (Table 1), is used by four authors [11,13-15]; on "BVS Biblioteca Virtual em Saúde - Literatura Técnico-Científica” - www.bireme.br/ - website 18 articles met our selection and on CTSNet - The Cardiothoracic Surgery Network http://www.ctsnet.org/ - five articles only. The term anterior interventricular artery, a nonofficial anatomical term, four authors used the term $[1,12,16,17]$; on BVS website and on CTSNet, 84 articles and four met our selection, respectively.

We have also found other options to the official anatomical term, such as: anterior interventricular branch (left anterior descending) of left coronary artery, one author [15]; anterior interventricular (anterior descending) branch, two authors [5,10]; anterior interventricular (anterior descending) branch, two authors [5,10]; and anterior interventricular branch of left coronary artery, one author [2].

Regarding the term Diagonal branch, the official anatomical term, one author has used it [15]; on "BVS Biblioteca Virtual em Saúde - Literatura Técnico-Científica” website - www.bireme.br/ - 25 articles met our selection and on CTSNet - The Cardiothoracic Surgery Network - http:/ /www.ctsnet.org/ - 353 articles. We have found also as nonofficial anatomical term, Diagonal artery, this term was used by one author [12]; on BVS - Biblioteca Virtual em Saúde - Literatura Técnico-Científica website www.bireme.br/ - 38 articles met our selection and on CTSNet - The Cardiothoracic Surgery Network - http:// www.ctsnet.org/ - 108 articles. Other options to the official term were as follows: diagonal branch of anterior interventricular branch, one author [2]; and lateral diagonal branch, three authors $[5,10,17]$.

With regard to posterior interventricular branch, the official anatomical term (Table 1) is used by five authors [1,11,13,14,18]; on BVS - Biblioteca Virtual em Saúde Literatura Técnico-Científica website - www.bireme.br/ two articles met our selection and on CTSNet - The Cardiothoracic Surgery Network - http://www.ctsnet.org/ one article only. As for the nonofficial term, Posterior interventricular artery, this term was used by two authors [12,16]; on BVS - Biblioteca Virtual em Saúde - Literatura Técnico-Científica website - www.bireme.br/ - 7 articles met our selection and on CTSNet - The Cardiothoracic Surgery Network - http://www.ctsnet.org/ - 5 articles.

Another possibility to the official term is as follows: posterior interventricular branch of right coronary artery, one author [2]; posterior interventricular (posterior descending) branch, one author [17]; posterior interventricular branch within posterior interventricular groove, two authors $[5,10]$; and posterior interventricular branch (posterior descending) of right coronary artery, one author [15].

As to the term circumflex branch, the official anatomical term (see Table 1), this term is used by five authors $[1,13,14,18]$; on BVS - Biblioteca Virtual em Saúde Literatura Técnico-Científica website - www.bireme.br/ 42 articles met our selection and on CTSNet - The Cardiothoracic Surgery Network - http://www.ctsnet.org/ 57 articles. Regarding the nonofficial term, circumflex artery, this was used by two authors [12,16]; on "BVS - Biblioteca Virtual em Saúde - Literatura Técnico-Científica” website www.bireme.br/ - 568 articles met our selection and on CTSNet - The Cardiothoracic Surgery Network - http:// www.ctsnet.org/ - 921 articles. Another alternative term used was circumflex branch of left coronary artery, which was employed by five authors $[2,5,11,15]$. 
Table 1. Main used official Cardiological Terms in Latin, English, Portuguese and Spanish.

\begin{tabular}{|c|c|c|c|}
\hline $\begin{array}{r}\text { LATIN } \\
\end{array}$ & ENGLISH & PORTUGUESE & SPANISH \\
\hline 1.Systema cardiovasculare & Cardiovascular system & Sistema circulatório & Sistema cardiovascular \\
\hline 2.Valva & Valve & Valva & Válvula \\
\hline 3.Valvula & Cusp & Válvula & Valva \\
\hline 4.Cuspis & Cusp & Válvula & Cúspide; Valva \\
\hline $\begin{array}{l}\text { 5.Valva atrioventricularis dextra; } \\
\text { Valva tricuspidalis }\end{array}$ & $\begin{array}{l}\text { Tricuspid valve; Right } \\
\text { atrioventricular valve }\end{array}$ & Valva atrioventricular direita & $\begin{array}{l}\text { Válvula atrioventricular } \\
\text { derecha; Válvula tricúspide }\end{array}$ \\
\hline 6.Cuspis anterior & Anterior cusp & Válvula anterior & Valva anterior \\
\hline 7.Cuspis posterior & Posterior cusp & Válvula posterior & Valva posterior \\
\hline 8.Valva trunci pulmonalis & Pulmonary valve & Valva do tronco pulmonar & Válvula pulmonar \\
\hline 9.Valvula semilunaris dextra & Right semilunar cusp & Válvula semilunar direita & Valva semilunar derecha \\
\hline 10.Valvula semilunaris sinistra & Left semilunar cusp & Válvula semilunar esquerda & Valva semilunar izquierda \\
\hline 11.Valvula semilunaris anterior & Anterior semilunar cusp & Válvula semilunar anterior & Valva semilunar anterior \\
\hline $\begin{array}{l}\text { 12.Valva atrioventricularis sinistra; } \\
\text { Valva mitralis }\end{array}$ & $\begin{array}{l}\text { Mitral valve; Left } \\
\text { atrioventricular valve }\end{array}$ & $\begin{array}{l}\text { Valva atrioventricular } \\
\text { esquerda }\end{array}$ & $\begin{array}{l}\text { Válvula atrioventricular } \\
\text { izquierda; Válvula mitral }\end{array}$ \\
\hline 13.Cuspis anterior & Anterior cusp & Válvula anterior & Valva anterior \\
\hline 14.Cuspis posterior & Posterior cusp & Válvula posterior & Valva posterior \\
\hline 15.Cuspides commissurales & Commissural cusps & Válvula comissural & Valvas comisurales \\
\hline $\begin{array}{l}\text { 16.Valvula semilunaris dextra; } \\
\text { Valvula coronária dextra }\end{array}$ & $\begin{array}{l}\text { Right semilunar cusp; Right } \\
\text { coronary cusp }\end{array}$ & Válvula semilunar direita & $\begin{array}{l}\text { Valve semilunar derecha; } \\
\text { Valva coronaria derecha }\end{array}$ \\
\hline $\begin{array}{l}\text { 17.Valvula semilunaris sinistra; } \\
\text { Valvula coronária sinistra }\end{array}$ & $\begin{array}{l}\text { Left semilunar cusp; Left } \\
\text { coronary cusp }\end{array}$ & Válvula semilunar esquerda & $\begin{array}{l}\text { Vlava semilunar izquierda; } \\
\text { Valva coronaria izquierda }\end{array}$ \\
\hline $\begin{array}{l}\text { 18.Valvula semilunaris posterior; } \\
\text { Valvula non coronária }\end{array}$ & $\begin{array}{l}\text { Posterior semilunar cusp; } \\
\text { Noncoronary cusps }\end{array}$ & Válvula semilunar posterior & $\begin{array}{l}\text { Valva semilunar posterior; } \\
\text { Valva no coronaria }\end{array}$ \\
\hline $\begin{array}{l}\text { 19.Complexus stimulans cordis; } \\
\text { Systema conducente cordis }\end{array}$ & Conducting system of heart & $\begin{array}{l}\text { Complexo estimulante do } \\
\text { coração }\end{array}$ & $\begin{array}{l}\text { Sistema de conducción del } \\
\text { corazón }\end{array}$ \\
\hline 20.Aorta & Aorta & Aorta & Aorta \\
\hline $\begin{array}{l}\text { 21.Pars ascendens aortae; Aorta } \\
\text { ascendens }\end{array}$ & Ascending aorta & Parte ascendente da aorta & Aorta ascendente \\
\hline 22.Arteria coronaria dextra & Right coronary artery & A. coronária direita & Arteria coronaria derecha \\
\hline 23.R. marginalis Dexter & Right marginal branch & R. marginal direito & R. marginal derecha \\
\hline 24.R. interventricularis posterior & $\begin{array}{l}\text { Posterior interventricular } \\
\text { branch }\end{array}$ & R. interventricular posterior & R. interventricular posterior \\
\hline 25.Arteria coronaria sinistra & Left coronary artery & A. coronária esquerda & Arteria coronaria izquierda \\
\hline 26.R. interventricularis anterior & $\begin{array}{l}\text { Anterior interventricular } \\
\text { branch }\end{array}$ & R. interventricular anterior & R.interventricular anterior \\
\hline 27.R. lateralis & Lateral branch & R. lateral & R. lateral \\
\hline 28.R. cirumflexus & Circumflex branch & R. circunflexo & R. circunfleja \\
\hline 29.R. marginalis sinister & Left marginal branch & R. marginal esquerdo & A. marginal izquierda \\
\hline $\begin{array}{l}\text { 30.A. marginalis coli; A. juxtacolica; } \\
\text { Arcus marginalis coli }\end{array}$ & $\begin{array}{l}\text { Marginal artery; juxtacolic } \\
\text { artery; Marginal árcade }\end{array}$ & Arco justacólico & $\begin{array}{l}\text { A. marginal del colon; A. } \\
\text { yuxtacólica; Arco marginal } \\
\text { del colon }\end{array}$ \\
\hline
\end{tabular}


Table 2. English, Portuguese, and Spanish main cardiological terms in common usage.

\begin{tabular}{|c|c|c|}
\hline ENGLISH & PORTUGUESE & SPANISH \\
\hline 1.Extracorporeal circulation & Circulação extracorpórea & Circulación extracorporea \\
\hline 2.Cardiopulmonary Bypass & Ponte Cardiopulmonar & Puente cardiopulmonar \\
\hline 3.Heart-Lung Bypass & Ponte Cardiopulmonar & Puente cardiopulmonar \\
\hline 4.Left Heart Bypass & Derivação Cardíaca Esquerda & Puente cardíaco izquierdo \\
\hline 5.Beating Heart Coronary Artery Bypass & $\begin{array}{l}\text { Ponte de Artéria Coronária sem Circulação } \\
\text { Extracorpórea }\end{array}$ & Puente de arteria coronaria off-pump \\
\hline 6.Off-Pump Coronary Artery Bypass & $\begin{array}{l}\text { Ponte de Artéria Coronária sem Circulação } \\
\text { Extracorpórea; Revascularização do miocárdio } \\
\text { sem circulação extracorpórea }\end{array}$ & $\begin{array}{l}\text { Puente de arteria coronaria off- } \\
\text { pump; Revascularización } \\
\text { miocárdica off-pump }\end{array}$ \\
\hline 7.Coronary Artery Bypass & Ponte de Artéria Coronária & Puente de arteria coronaria \\
\hline 8.Aortocoronary Bypass & Ponte de Artéria Coronária & Puente de arteria coronaria \\
\hline 9.Coronary Artery Disease & Doença da Artéria Coronariana & Enfermedad de la arteria coronaria \\
\hline 10.Coronary arteriosclerosis & Doença da Artéria Coronariana & Enfermedad de la arteria coronaria \\
\hline 11.Coronary atherosclerosis & Doença da Artéria Coronariana & Enfermedad de la arteria coronaria \\
\hline 12. Heart Arrest & Parada Cardíaca & Paro cardíaco \\
\hline 13.Cardiopulmonary arrest & Parada Cardíaca & Paro cardíaco \\
\hline 14.Cardiac Arrest & Parada Cardíaca & Paro cardíaco \\
\hline 15.Cardiopulmonary Resuscitation & Ressuscitação Cardiopulmonar & Resucitación cardiopulmonar \\
\hline 16.Basic Cardiac Life Support & Ressuscitação Cardiopulmonar & Resucitación cardiopulmonar \\
\hline 17. Heart sounds & Ruídos cardíacos & Ruidos cardíacos \\
\hline 18. Heart murmurs & Sopros cardíacos & Soplos cardíacos \\
\hline 19.Heart block & Bloqueio cardíaco & Bloqueo cardíaco \\
\hline 20.Right heart bypass & Derivação cardíaca direita & Puente cardíaco derecho \\
\hline 21.Heart-Assist pumps & Coração Auxiliar & Corazón auxiliar \\
\hline 22.Vascular-assist devices & Coração auxiliar & Corazón auxiliar \\
\hline 23.Cardiopulmonary bypass & Circulação extracorpórea & Circulación extracorpórea \\
\hline 24.High cardiac output & Débito cardíaco elevado & Alto gasto cardíaco \\
\hline 25.Reduced cardiac oxygen output & Débito de oxigênio cardíaco reduzido & Bajo gasto de oxígeno cardíaco \\
\hline 26.Low cardiac output & Baixo débito cardíaco & Bajo gasto cardíaco \\
\hline 27.Thoracic injuries & Traumatismos torácicos & Traumatismos torácicos \\
\hline 28. Heart diseases & Cardiopatias & Cardiopatías \\
\hline 29.Surgical wound infection & Infecção da ferida operatória & Infección de herida operatoria \\
\hline 30.Postoperative wound infection & Infecção de ferida pós-operatória & Infección de herida postoperatoria \\
\hline
\end{tabular}


Concerning the specialized dictionaries $(\mathrm{n}=3)$ examined, we have found the following situation: the Stedman's Medical Dictionary $[19,20]$ registers the nonofficial anatomical terms, however, the synonymous used is the official anatomical term and its translation to Portuguese the Nomina Anatomica (Terminologia Anatômica, Tradução CTA-SBA [21], is used, that is, the official terminology. For example: Anterior interventricular artery (EM) - Ramo interventricular anterior da a. coronária esquerda PTBr); synonym: anterior interventricular branch of left coronary artery. Regarding the Dorland's Illustrated Medical Dictionary [22,23], all the terms are registered using the nonofficial terminology; it registers the referent in Latin and the translation to Portuguese is completely wrong with regard to the official Nomina Anatomica (Terminologia Anatômica, Tradução CTA-SBA, 2001). The "Glossário de Termos Médicos” [24] (Medical Terms Glossary, free translation)-English-Portuguese, registers the non official terminology, the official terminology, and the official anatomical translation. For example, anterior interventricular artery (see anterior interventricular branch) is translated as Ramo interventricular anterior da A. coronária esquerda.

Another example of the distance between official and nonofficial terminologies relies on well-established terms known world-wide such as Mitral Valve and Tricuspid Valve. The English official terminology has established as the official term, Mitral Valve, and as an alternative official term, Left Atrioventricular Valve. The Brazilian Terminology Committee has established the term Valva atrioventricular esquerda, as the official terminology. Likewise, the same happens to another official anatomical term, Tricuspid Valve. The alternative official term is Right Atrioventricular Valve; while in Portuguese the official anatomical term is Valva atrioventricular direita only.

In the Terminología Anatómica [25], in Spanish, as we can observe in the appendage $\mathrm{A}$, the official anatomical term is Válvula atrioventricular derecha; the alternative official term is Válvula tricúspide; the same is true for Válvula atrioventricular izquierda, the official anatomical, while the alternative official term is Válvula mitral.

It is difficult to generalize, but it can be said that, on the whole, as abovementioned, our health science practitioners are not aware of the new terminology, once it is worth remembering here that the Nomina Anatomica [26], $5^{\text {th }}$ ed., approved by the $11^{\text {th }}$ International Congress of Anatomists, Mexico, 1980, and published in Brasil in 1984, had already the terms written in Portuguese, such as Valva atrioventricular direita (Right Atrioventricular Valve) and Valva atrioventricular esquerda (Left Atrioventricular Valve).

\section{CONCLUDINGREMARKS}

There is no consensus regarding the use of official anatomical terms. Usual or nonofficial technical terms which lead to terminology or translation misunderstanding is often a source of confusion to practitioners and translators worldwide. Because anatomical terminology is the foundation of medical terminology and language, it is important that physicians and scientists, as well as all the Allied Health Sciences practitioners throughout the world use the same name for each structure. Physicians must be aware of the new Terminologia Anatomica, which is the joint creation of the Federative Committee on Anatomical Terminology (FCAT). They all must learn the correct nomenclature that enables precise communication among practitioners worldwide, as well as among scholars in basic and applied health sciences.

\section{REFERENCES}

1. Snell RS. Clinical anatomy for medical students. 5th ed. Boston:Little, Brown and Company;1995.

2. Drake RL, Vogl W, Mitchel AWM. Gray's anatomy for students. Philadelphia:Elsevier;2005.

3. Chabner D-E. The language of medicine. 2nd ed. Philadelphia:WB Saunders;1981.

4. Aubert FH. Introdução à metodologia da pesquisa terminológica bilíngüe. São Paulo:Humanitas Publicações, FFLCH/ USP;1996. [Cadernos de Terminologia, 2]

5. Moore KL, Agur AMR. Essential clinical anatomy. 2nd ed. Baltimore:Lippincott Williams \& Wilkins;2002.

6. Federative Committee on Anatomical Terminology. Terminologia anatomica. Stuttgart:Thieme Buch;1998.

7. Barbosa MA. Dicionário, vocabulário, glossário: concepções. São Paulo:CITRAT/FFLCH/USP;1996. [Cadernos de Terminologia, 1]

8. Barros LA. Curso básico de terminologia. São Paulo:Edusp;2004.

9. Persaud TVN. Early history of human anatomy from antiquity to the beginning of the modern era. Springfield:Charles C. Thomas;1984 apud Moore KL, Dalley II AF. Clinically oriented anatomy. 4th ed. Baltimore:Lippincott Williams \& Wilkins;1999. 
10. Moore KL, Dalley II AF. Clinically oriented anatomy. 4th ed. Baltimore:Lippincott Williams \& Wilkins;1999.

11. O’Rahilly R. Basic human anatomy. Philadelphia:WB Saunders;1983.

12. Williams PL, Bannister LH, Berry MM, editors. Gray’s anatomy. 37th ed. London:Churchill Livingstone;1989.

13. Tortora GJ, Grabowski SR. Principles of anatomy and physiology. 9th ed. New York:John Wiley \& Sons;2000.

14. Tortora GJ, Derrickson B. Principles of anatomy and physiology. 12th ed. Hoboken:John Wiley \& Sons;2009.

15. Tank PW, Gest TR, Burkel W. Atlas of anatomy. Philadelphia:Wolters Kluwer Health, Lippincott Williams \& Wilkins;2009.

16. Ellis H. Clinical anatomy: a revision and applied anatomy for clinical students. 9th ed. Oxford:Balckwell Science;1997.

17. Agur AMR, Dalley AF. Grant's atlas of anatomy. 11th ed. Baltimore:Lippincott Williams \& Wilkins;2005.

18. Tortora GJ. Principles of human anatomy. 10th ed. Hoboken:John Wiley \& Sons;2005.
19. Stedman's medical dictionary. Baltimore:Lippincott Williams \& Wilkins;2000.

20. Stedman's online medical dictionary [monograph online]. 27th ed. Baltimore:Lippincott Williams \& Wilkins;2009. [cited 2009 Feb 12]. Available from: URL: www.stedmans.com/ section.cfm $/ 45$

21. Terminologia anatômica. Tradução de CTA-SBA. $1^{\text {a }}$ ed. brasileira. São Paulo:Manole;2001.

22. Dicionário médico ilustrado Dorland. Tradução de Dr. Nelson Gomes de Oliveira. São Paulo:Manole;1999.

23. MerckSource. Dorland's medical dictionary for health consumers [monograph online]. Philadelphia:WB Saunders,Elsevier;2007. [cited 2009 Feb 12]. Available from:www.mercksource.com/pp/ us/cns/cns_hl_dorlands_split.jsp?pg=/ppdocs/us/common/ dorlands/dorland/misc/M_1_TOC.htm

24. Werneck AL. Glossário de termos médicos. São Paulo:Disal;2007.

25. Terminología anatómica. $1^{\mathrm{a}}$ ed. Madrid:Médica Panamericana;2001.

26. Nomina anatomica. Rio de Janeiro:Medsi;1984. 